\title{
JOURNAL OF DEVELOPMENTAL ORIGINS OF HEALTH AND DISEASE
}
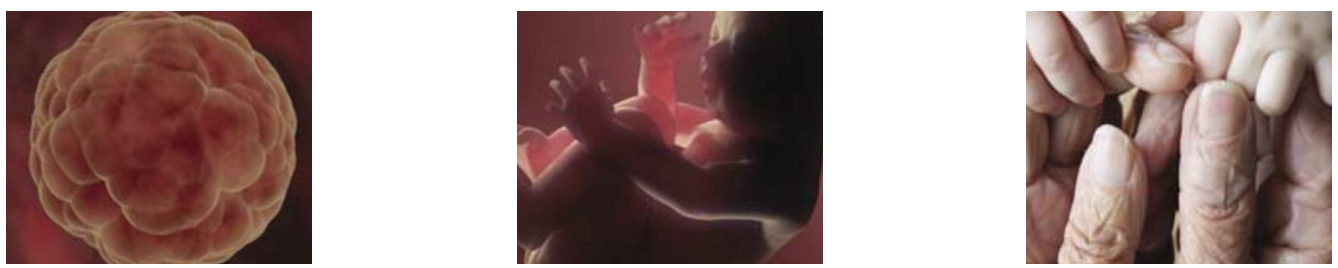

\section{CONTENTS}

IN THIS ISSUE

Michael G. Ross

\section{ORIGINAL ARTICLES}

Self-reported depression and anxiety after prenatal famine exposure: mediation by cardio-metabolic pathology?

S. R. de Rooij, R. C. Painter, D. I. Phillips, K. Räikkönen,

A. H. Schene and T. J. Roseboom

Anthropometry from birth to 24 months among offspring of women with gestational diabetes: 2004 Pelotas Birth Cohort M. A. S. O. Dode, I. S. Santos and D. A. González

Psychosocial determinants of cigarette smoking among university students in Jordan

M. Farajat, C. Hoving and H. De Vries

Exposure to maternal smoking during fetal life affects food preferences in adulthood independent of the effects of intrauterine growth restriction

C. Ayres, P. P. Silveira, M. A. Barbieri, A. K. Portella, H. Bettiol, M. Agranonik, A. A. Silva and M. Z. Goldani
Maternal low-protein diet suppresses vascular and renal endothelial nitric oxide synthase phosphorylation in rat offspring independent of a postnatal fructose diet

S. Sato, Y. Mukai and T. Norikura

Branched-chain amino acid supplemented diet during maternal food restriction prevents developmental hypertension in adult rat offspring

T. Fujii, S. Yura, K. Tatsumi, E. Kondoh, H. Mogami, K. Fujita, K. Kakui, S. Aoe, H. Itoh, N. Sagawa, S. Fujii and I. Konishi

Neonatal oxygen exposure leads to increased aortic wall stiffness in adult rats: a Doppler ultrasound study

Y. Mivelaz, C. Yzydorczyk, A. Barbier, A. Cloutier, J. C. Fouron, D. de Blois and A. M. Nuyt

\section{BRIEF REPORT}

Cultured neonatal rat cardiomyocytes display differences in glucose uptake and sensitivity to dexamethasone related to maternal diet 


\section{EDITORIAL POLICY}

Journal of Developmental Origins of Health and Disease publishes leading research in the field of developmental origins of health and disease (DOHaD), focusing on how the environment during early animal and human development, and interactions between environmental and genetic factors, influence health in later life and risk of disease. It publishes original research articles, short communications and reviews, and plans regular themed issues, with guest editors; it is also a platform for conference/workshop reports, and for opinion, comment and interaction. The journal is multi-disciplinary, with contributions from basic scientists working in the fields of physiology, nutrition, endocrinology and metabolism, developmental biology, molecular biology and epigenetics, human biology and anthropology, evolutionary developmental biology, and clinicians, nutritionists, epidemiologists, social scientists, economists, public health specialists and policy makers.

\section{SUBSCRIPTIONS}

Journal of Developmental Origins of Health and Disease (print ISSN 2040-1744, electronic ISSN 2040-1752) is published bimonthly in February, April, June, August, October and December, 6 parts forming a volume, by Cambridge University Press, The Edinburgh Building, Shaftesbury Road, Cambridge CB2 8RU, UK/Cambridge University Press, 32 Avenue of the Americas, New York, NY 10013-2473, USA. The institutional subscription price (excluding VAT) including electronic access of Volume 2 (2011) is f250 net (US $\$ 413$ in the USA, Canada and Mexico). The electronic-only price available to institutional subscribers is f210 (US \$347 in USA, Canada and Mexico). The print-only price available to institutional subscribers is $\mathrm{f} 230$ (US $\$ 380$ in the USA, Canada and Mexico) Single parts are $£ 42$ (US $\$ 70$ in the USA, Canada and Mexico) plus postage. Back volumes are also available.

Orders, which must be accompanied by payment, may be sent to a bookseller, subscription agent or direct to the publisher: Cambridge University Press, The Edinburgh Building, Shaftesbury Road, Cambridge CB2 8RU, UK; or in the USA, Canada and Mexico: Cambridge University Press, Journals Fulfillment Department, 100 Brook Hill Drive, West Nyack, New York 10994-2133. EU subscribers (outside the UK) who are not registered for VAT should add VAT at their country's rate. VAT registered subscribers should provide their VAT registration number. Japanese prices for institutions are available from Kinokuniya Company Ltd, PO Box 55, Chitose, Tokyo 156, Japan. Prices include delivery by air.

\section{DOHAD MEMBERS SUBSCRIPTION}

Members of the International Society for Developmental Origins of Health and Disease $(\mathrm{DOH} \mathrm{HD})$ receive electronic access to the journal as part of their subscription to the Society (Standard membership rate: $£ 45$ / US $\$ 70$ / €50; Student membership rate: $f 20$ / US $\$ 30$ / €22; Developing Country rate: see www.mrc.soton.ac.uk/dohad). For membership application details please visit www.mrc.soton.ac.uk/dohad. For additional print subscription members are asked to contact the Membership Secretary (dohad@mrc.soton.ac.uk) at DOHaD.

\section{COPYRIGHT AND PERMISSIONS}

This journal is registered with the Copyright Clearance Center, 222 Rosewood Drive, Danvers, MA 01923, USA. Organizations in the USA who are also registered with C.C.C. may therefore copy material (beyond the limits permitted by sections 107 and 108 of U.S. Copyright law) subject to payment to C.C.C. of the per-copy fee of $\$ 25.00$. This consent does not extend to multiple copying for promotional or commercial purposes.

Code 2040-1744/2011 \$25.00.

ISI Tear Sheet Service, 3501 Market Street, Philadelphia, PA 19104, USA, is authorized to supply single copies of separate articles for private use only.

Organizations authorized by the Copyright Licensing Agency may also copy material subject to the usual conditions.

For all other use, permission should be sought from Cambridge or the American Branch of Cambridge University Press.

\section{ABSTRACTING AND INDEXING}

Journal of Developmental Origins of Health and Disease is covered by Science Citation Index Expanded (also known as SciSearch ${ }^{\circledR}$ ), Biosis Abstracts, and Biosis Previews.

\section{ADVERTISING}

Advertising queries for all parts of the world except the USA, Canada and Mexico to: ad_sales@cambridge.org

Address enquiries in the USA, Mexico and Canada only to:

journals_advertising@cup.org

\section{OTHER BUSINESS CORRESPONDENCE}

All other business correspondence should be sent to Dan Edwards, Commissioning Editor: dedwards@cambridge.org

\section{INSTRUCTIONS FOR CONTRIBUTORS}

Full Instructions for Contributors are available for download from journals.cambridge.org/doh

\section{INTERNET ACCESS}

This journal is included in the Cambridge Journals Online service which can be found at journals.cambridge.org. For further information on other Press titles access cambridge.org

\section{DISCLAIMER}

The views expressed in this journal represent those of the authors only. In no way can they be construed to necessarily reflect the views of either the Editors, the Publishers, or the Society.

(C) Cambridge University Press and the International Society for Developmental Origins of Health and Disease 2011

Printed in the United Kingdom by Latimer Trend, Plymouth

This journal issue has been printed on FSC-certified paper and cover board. FSC is an independent, non-governmental, not-for-profit organization established to promote the responsible management of the world's forests. Please see www.fsc.org for information. 
https://doi.org/10.1017/S2040174411000225 Published online by Cambridge University Press 


\section{CAMBRIDGE}

\section{JOURNALS}
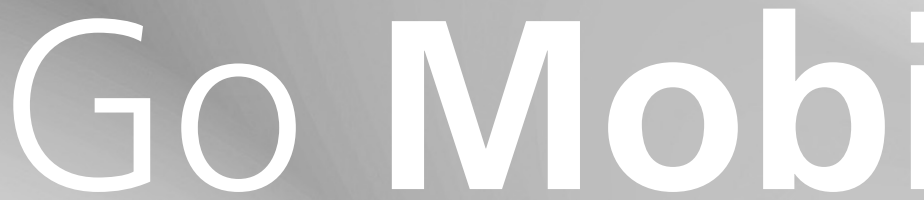

CJO Mobile (CJOm) is a streamlined

Cambridge Journals Online (CJO)

for smartphones and other

small mobile devices

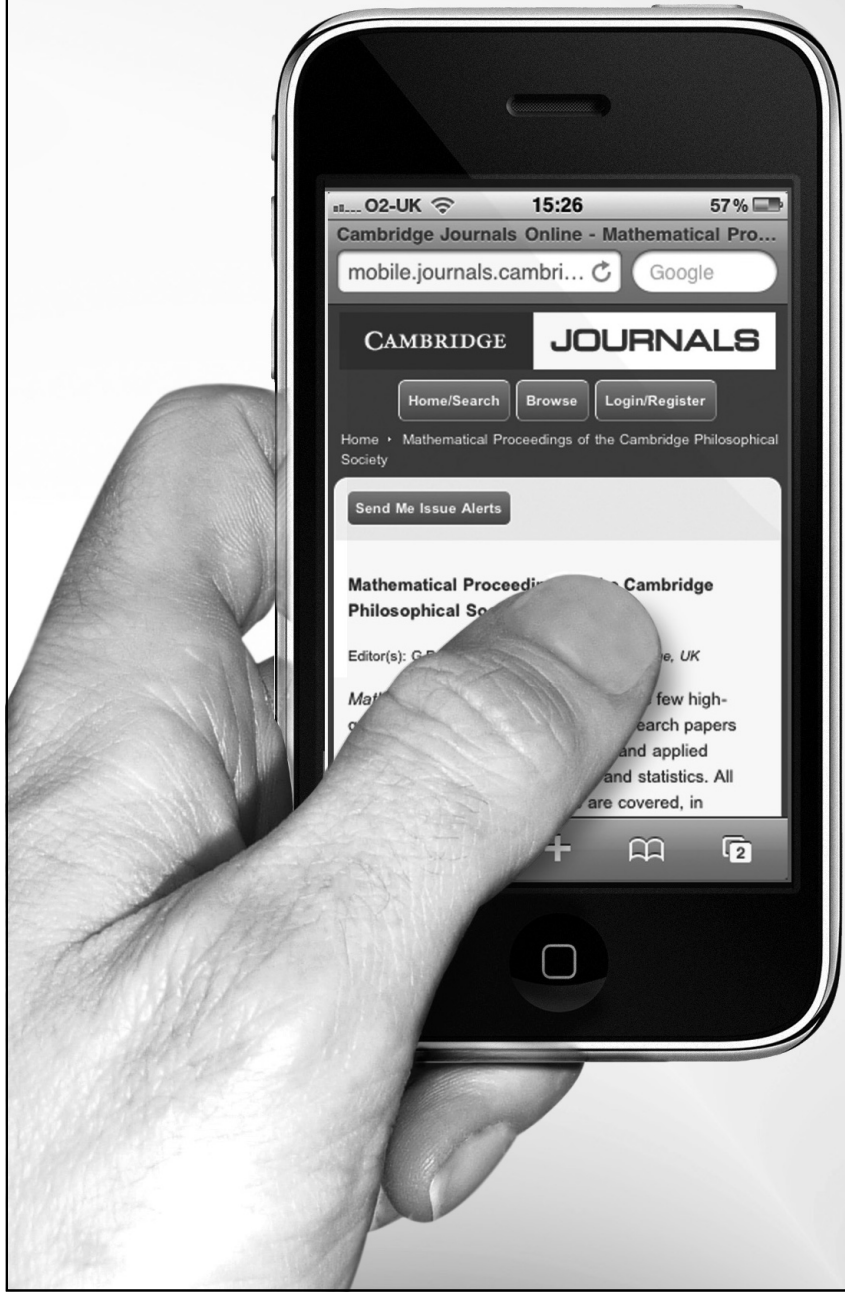

- Use CJOm to access all journal content including FirstView articles which are published online ahead of print

- Access quickly and easily thanks to simplified design and low resolution images

- Register for content alerts or save searches and articles they will be available on both CJO and CJOm

- Your device will be detected and automatically directed to CJOm via: journals.cambridge.org 